\title{
Behaviour and Process in the formation of the North European Acheulean Record: Towards a Unified Palaeolithic Landscape Approach
}

\author{
Matt Pope ${ }^{1}$, Lesley Blundell ${ }^{1}$, Beccy Scott ${ }^{2}$ and Hannah Cutler ${ }^{3}$ \\ 1. Institute of Archaeology, University College London. \\ 2. British Museum. Department of Britain, Europe and Prehistory. \\ 3. Suffolk County Council
}

\begin{abstract}
The Acheulean record of northern France and southern Britain has long been acknowledged as internationally important, having played an important historical role in the development of the discipline. Abundant artefacts have been recovered, primarily from fluvial gravel archives, allowing the responses of Middle Pleistocene human populations on the edge of their geographical distribution to be interrogated. The richness of the record from such deposits can most simply be read as reflecting absolute population numbers - and changes in this over time. However, factors such as regional superabundance of high quality flint (related to solid geology) and intensity of aggregate exploitation also played their part in generating the apparently regionally dense record of finds. This paper investigates the inter-related patterns of human behaviour, preservation, artefact release and research tradition which underpin these basic distribution maps. We here present a framework for understanding the processes which have created the current distribution map - in terms of where we find material, and which periods are best represented within it. We term this the Unified Palaeolithic Landscape Approach and outline ways in which the spatial and temporal range of the Acheulean record can be addressed through the archaeological record of its heartland.
\end{abstract}

\section{Geology and Palaeolithic Research History in Cretaceous Northern Europe}

The rich Lower and Middle Palaeolithic record of Southern Britain and North France as currently mapped (Figure 1) emerged through the interaction of three regularly considered factors. Firstly much of our data was collected in the late $19^{\text {th }}$ century and early $20^{\text {th }}$ century in the wake of Joseph Prestwich's (1859) publication of the proof of the antiquity of humanity. The explosion of scientific interest, and efforts in documenting prehistoric implements and their geological contexts as well as securing specimens and collections for the burgeoning public museums, which expanded at this time contributed hugely to our core dataset. Secondly, the birth and expansion of human origins studies coincided with an industrial and engineering revolution that was hungry for raw materials extracted, by hand, from the landscape - clays, minerals and aggregate. The traces of human behaviour recovered from within these deposits was undoubtedly skewed in favour of Acheulean handaxes being abundant, large and very visible artefacts. Handaxes were more readily noted by quarry workers and passed through to collectors and academics to a greater degree than other artefact classes. 
Throughout the late $20^{\text {th }}$ and early $21^{\text {st }}$ century, the transition to mechanised aggregate extraction meant that fewer new northern Europe sites were encountered. Understanding of the existing record, however, was drastically transformed through the development of a fully multi-disciplinary approach to Quaternary environments and past human behaviour. In Britain, John Wymer (Wymer 1968, 1985, 1999) and Derek Roe (Roe 1964, 1968, 1981a), 1981b) developed definitive national gazetteers of Lower Palaeolithic find spots, and established basic sequences of techno-cultural development within the region, leading to an appreciation of the extent - and richness - of the regional record. Work to develop basic sequences of valley development and climate history (e.g. Bridgland 1994), combined with the development of a Marine Isotope Framework (Shackleton and Opdyke 1973) transformed the chronological framework for our occupation history (White and Schreve 2000). The record of find spots was further enhanced by The English and Southern Rivers Projects (Wessex Archaeology 1993, 1999), and fieldwork by the Ancient Human of Occupation of Britain project. These developments expanded the chronology of the British Palaeolithic back to at least 780,000 years (Parfitt et al 2005, Parfitt et a/ 2010), and developed a demographic model for the colonisation, and apparent late Middle Pleistocene depopulation, of Britain (Ashton and Lewis 2002).

Whilst this historical confluence, of academic and industrial ambition, brought large quantities of material and many of the dots on our base-maps of the Palaeolithic to light, it also shaped greatly where and how our past became visible. Historical contingency acted as a lens through which the geographical distribution of the Palaeolithic became both viewed and through which it was almost certainly skewed. Bearing this in mind, the third factor that shaped the Acheulean record - past human behaviour - can only be properly brought into focus once we consider carefully how that record was formed. These three factors, two of which can be understood through historical enquiry (history of the discipline / industry), and a third which forms the target of our research (past human behaviour), are those most often considered to have shaped the big data providing the bedrock of our understanding of the north European Acheulean (Hosfield 1999). Without a radical transformation in the scope and scale of field research (dedicated site prospection or archaeological responses to a return to large scale hand quarrying) the nature of this dataset is unlikely to change in terms of the number of sites, or overall distribution pattern.

It is therefore vital that, in the absence of large volumes of new data, we consider the information we have even more critically, and use it in smarter ways. In order to test and expand it's limits, in order to determine what it can, and cannot, tell us about the deep human past, we need to carefully consider wider factors that have acted as filters to our understanding of past human behaviour, demography and paleoecology. In this paper we explore this scope by intensifying our focus on a fourth key factor in the formation of Palaeolithic record, and one which currently lacks an identifiable framework for analysis: the geomorphological controls over artefact preservation and recovery.

Whereas site formation processes are now regularly addressed at the site or palaeolandscape level, there seems to scant consideration of landscape formation processes involved in the formation of the extant data-set when working with larger-scale (national and regional) patterns. In this paper we aim to highlight just how profound the effects of these processes upon the characteristics and distribution of our core regional datasets might be for Palaeolithic as a whole. We do this by first considering the record of Acheulean handaxe findspots within the north European cretaceous region (between northern France and southern Britain). Handaxes are chosen as the primary dataset here as the Acheulean forms the focus of our current research, they also provide a consistent dataset in terms of 
size, shape and recognisability. Our assumption is that, by focusing on handaxes in the first instance, the effects of collector bias, when compared to the flaked based technologies of the Clactonian or Levalloisian will be greatly reduced.

Developing an analytical framework which consider finds within their wider geomorphological context, as a part of a single, unified sedimentary systems rather than a fragmented archive of sediment bodies is key to addressing process in the formation of the record. Exploring the relationship between site distribution patterns and the interconnectivity of other landscape contexts - hilltops, slope, fluvial and gelifluction deposits will necessitate a fuller consideration of process than is currently the case. We contend that only once the temporal and spatially structuring effects of processes upon the extant record is properly considered can we proceed to interpretations of past human behaviour based.

\section{Towards a Unified Palaeolithic Landscape Approach}

In order to bring this fourth, process-driven, dynamic behind our Acheulean data to the foreground, we prose the development of a Unified Palaeolithic Landscape Approach (UPLA) to the record. The UPLA should be a framework which addresses how the known Palaeolithic record is structured, by considering how particular parts of the record are preserved and become visible. Whilst such questions are routinely asked for individual sites, taking a distribution-led approach requires that we address these questions for the landscapes across which the record is distributed. The UPLA seeks to foreground and make explicit the complexities which lie behind the formation of the extant archaeological record, and thus to develop more nuanced readings of how we interpret this. To this end, three factors must be considered: behaviour, preservation and release (see below). Whilst these are explicitly addressed at the site level, they are often only obliquely interrogated - if at all - when considering spatial distribution or temporal patterning. It is this point that we wish to address through a Unified Palaeolithic Landscape Approach: that we cannot discard the taphonomic necessities of dealing with the Palaeolithic simply by levelling up to a distribution-led scale of analysis.

\section{Behaviour}

The "original" archaeological signature of past human behaviour within a broad landscape is interpreted from the residues that 'drop out' from human populations at particular places (Schlanger 1992; Pope 2002; Conneller 2011). That the Acheulean record is not uniformly distributed across the landscape is obviously attested both by variation in the quantity of artefacts and disaggregation of the chaîne opératoire within sites (eg. Boxgrove Palaeolandscape, Cagny sites of the Somme: Roberts and Parfitt 1999; Hallos 2005; Tuffreau et al 1997). The role that such locales played within hominin landscapes is read off from the sites themselves, in relation to one another, based on the material discarded at them: a "site-up" perspective on the patterning seen in human landuse practices. Discard may therefore be biased towards locations where resupply is more achievable, or at locales which are repeatedly visited. However, from the point of view of building "distribution-down", such material has a variable chance of entering sedimentary systems within which such traces could be preserved.

\section{Preservation}


If a behavioural pattern (such as raw material extraction at floodplain edge) coincides with a preservational pattern (net sedimentation from adjacent slope and overbank flooding; reduced chance of destruction through channel incision compared with central floodplain), then such patterns are exponentially intensified. From the site up, such interplays are carefully evaluated (eg. the Somme Valley: see Tuffreau et al 1997). Arguing from "distribution-down" however, is more problematic: for instance, simplistic contrasts (upland/valley bottom) may be asserted between different parts of the same geomorphological landscape, which thus become analytically atomised and disconnected.

Preservation potential thus impacts upon spatial distribution in one way (likelihood of entering the record), but it also affects what is being sampled. An accumulation of rolled artefacts from a fluvial gravel reflects human behaviour throughout the landscape catchment from which it derives; refitting artefacts sealed by loess reflect human presence at that particular place and time. This is not a new observation (see Gamble 1996, for example) but it is a critical asymmetry across the record of any given landscape, and one which we examine below through the example of habitat preference. When time and space averaged accumulations (river gravel, head deposit) are contrasted with near-primary context upland sites, then we are not comparing like with like. Such occurrences cannot be treated as equivalent: this is particularly problematic when exploring spatial patterning, as we discuss below

\section{Release}

Preservation over the long time scales of the Pleistocene requires stable sedimentary conditions. In sedimentary terms, stability requires isolation and protection from ongoing erosive processes. Isolation and protection relate primarily to two factors which vary across geomorphological systems: topographical distance from erosive points in the system (eg. scarp or channel edge) and burial depth (which similarly insulates archaeological residues from erosive processes). Thus, for instance, plateau centre sites are topographically isolated: deeply buried sites (e.g. infilled fissures or dolines) in the centre of interfluves are isolated and protected. However, to all intents and purposes, they are rarely archaeologically visible.

The archaeological record only comes into being when material is released from the context within which it is buried. Consequently, areas where Palaeolithic material has the potential to be preserved are, by definition, places where the rates of erosion, exposure and release are historically minimised. Artefacts are only released through essentially destructive processes - the very processes, however, that allow that object to be discovered. Release mechanisms can be natural (e.g. fluvial erosion or slope movement) or artificial (aggregate extraction or ploughing). Release processes are dependent on many environmental or socio-economic variables. However, in the geomorphological systems that have dominated cretaceous northern Europe, the dominant processes that control release are, on one hand, climatic cold-warm stage cycles of the Pleistocene (natural release) and, on the other, mineral extraction and development (artificial release). As high levels of release also equate with high levels of destruction, our sample, and the Acheulean record as a whole, has always been driven by release to a greater extent than by preservation or past human behaviours.

Integrating Behaviour, Preservation and Release in the Unified Palaeolithic Landscape Approach.

Whilst making sense of the complex variables outlined above is the ultimate aim of the UPLA, its initial focus is the overall distribution of mapped Lower Palaeolithic sites and findspots. This distribution is dominated by finds of handaxes, and in many ways represents the coarsest level of aggregate data, 
conflating long periods of time and complex formation processes. Whilst this complexity and conflation could discourage systematic investigation of the factors outlined above, it is actually through working at this coarse level, though making intra- and inter-regional comparisons, that we can investigate the processes of preservation and release acting upon the record, and ultimately bring into focus the patterns of human behaviour which underlie them.

Seen from this perspective, and from our previous work, the following observations can be made concerning artefact distribution:

1. Gaps in distribution patterns on maps are normally interpreted as evidence that people did not discard material in these areas. However, gaps might actually indicate a relatively well preserved landscape within which potential for artefact release is therefore low.

2. Distribution maps only indicate where release (artificial or natural) is taking place or has taken place over the past 160 years.

3. The geomorphological histories of these landscapes are complex, and the histories of erosional processes which underpin artefact release should be expected to have varied over time. This has implications for the reconstruction of changing palaeolandscapes, as well as understanding how intensively artefacts have been released from primary preservational contexts in the past.

Bearing these observations in mind, we now consider the North European Acheulean and ask what our distribution maps can and cannot tell us about past human behaviour, and thus what questions can actually be asked of them. We will consider two specific examples: the Acheulean record of human demography and identifying habitat preference in the Middle Pleistocene. However, before turning to these examples, it is necessary to outline the geomorphological processes affecting the Acheulean landscapes of the region.

\section{Preservation and Release: The geomorphology of the La Manche Chalklands}

Acheulean handaxes have been recovered in large numbers from the chalklands on both sides of the Channel. In Northern France, loess-mantled chalk plateaux are recognised as a context within which there is high potential for such material to occur (eg. see Locht 2010). In contrast, in southern Britain, equivalent plateau situations are viewed as marginal Palaeolithic landscapes and protection/research is weighted hugely in favour of fluvial terrace deposits as high potential contexts. Consequently, the North French record provides an important heuristic for comparison with that from Britain.

As a heavily jointed rock, Chalk is resistant to surface erosion. As a soft, calcareous rock, it dissolves relatively easily in response to the through-put of ground water. These effects are compounded by permafrost formation and the freeze-thaw effects associated with glacial cycling. When wet, Chalk is extremely susceptible to frost: ice-segregation is the likely cause of Chalk brecciation (Murton and Latridou 2003, 305) and periglacial solifluction on slopes, especially where soils are rich in silt and clay (Murton and Latridou 2003, 301). Conversely, thawing of frozen ground (i.e. with transition to warm conditions) is the likely cause of many of the deformation structures associated with periglacial features in Chalk, reflecting the mobility of these sediments (and the brecciated chalk) at transitions to warmer conditions. Where Chalk was affected by permafrost, very rapid valley formation is posited with increased throughput of water, marked by well-developed dry valleys and misfit streams, eroded chalky rubble being redeposited very close to its origin point as a fan. For instance, at the "Devil's 
Kneadingtrough" near Wye (Kent), material eroded during the Younger Dryas forms a fan within a one kilometre radius of the dry scarp valley suggested as its source (Preece 1998). In arctic and subarctic regions today, gullies form rapidly along lines of weakness - for instance, along ice-wedge casts (Murton and Latridou 2003, 306).

Throughout the Lower and Middle Palaeolithic, the cumulative effects of deep freeze-thaw cycling in response to global climate change are likely to have profoundly affected the form of the landscape, although specific regional factors control in what ways, and to what extent, in different regions. The distribution of Devensian permafrost, based on the occurrence of dated periglacial features, has been suggested to have affected all of Britain south of the ice sheet, with the exception of areas west of the Sussex coastal plain, the western Weald and the Oxford district (Williams 1965). Taking the Devensian as a measure of glacial impact on the landscape, more extensive, earlier glaciations may have seen similar continuous permafrost, but even its discontinuous presence would have resulted in the same changes to the landscape in response to shifts in climate. These repeated, deep, and rapid erosive episodes are overprinted on the modern Chalk downland.

However, the Chalk-dominated landscapes cut through by the Thames Valley and northern side of the Channel differ in one significant regard from those south of the Channel: significant deposits of loess were deposited across the continent throughout the Pleistocene (up to $100 \mathrm{~m}$ thick in Eastern Europe (Haase et al. 2007, 1307). Loess, as a fine grained, aggrading sediment, has great potential to preserve ethnographic-scale evidence of human behaviour. The exceptional archaeological records of the Somme and Maas Valleys reflect the depth of loess deposited within in them (Locht et al. 2014; Antoine et al. 2014), whilst in Britain, surviving loess coverage is minimal, largely restricted to the dip slope of the North Downs facing the Thames Valley and North Sea basin. Being the first terrestrial surface to face into this landscape, the North Downs received the thickest accumulation of regional loess fall anywhere in Britain, with a section approaching $4 \mathrm{~m}$ thick being recorded at Pegwell Bay, the earliest TL date for which is very recent, at 18 Kya (Murton et al 1998, 38). Substantial thicknesses of loess (and loess-derived slope deposits) are also recorded in and around Faversham (e.g. Bapchild, Ospringe). Such deposits are unknown, except within very isolated capture points, on the South Downs, which are more steeply inclined and prone to loss of surface cover through subaerial erosion.

Northern France and the Paris Basin represent the northerly limits of where significant accumulations of loess were deposited and remain preserved across the landscape. The significance of widespread loess deposition for preserving a fine-grained archaeological record is one implication of this, but thick loess also acts to preserve and stabilise the landscape as a whole (Antoine et al., 2007). Within the Paris Basin and across Flanders, loess mantles the Chalk and Palaeogene landscape, rendering it flat and featureless. In contrast to southern England, successive cold stages south of the Channel have resulted in net sedimentation through loess fall. This blanket of loess served to protect the Chalk from brecciation, restricting rapid valley formation, and, where deeper capture points exist (Palaeovalley infill, dolines and other karstic features), records a deep regional sequence of changing climate (Antoine et al. 2014). This is illustrated in Figure 1, which compares the key fluvial terrace sequences of the Somme and the Thames valleys. They differ not only in temporal extent (number of terraces), but also in the degree to which loessic head and associated land surfaces are preserved within each cold phase. This "blanketing effect" of loess cover is compounded by suggestions that periglacial features attributed to permafrost formation in Picardy/Normandy are restricted compared to Britain and Belgium (i.e. soil veins and frost wedges, with occasional ice wedge casts only on west-facing hills; 
Murton and Latridou 2003). The erosion of the chalklands bordering the Channel can therefore be characterised as controlled by two interlinked factors - permafrost formation (proximity to ice sheet decreasing south of the Channel) versus net sedimentation through loess deposition. In Northern France, sedimentation dominates, preserving both individual sites and palaeolandscape, whereas in Britain, these processes interact differently in different regions.

For example, when one compares the North and South Downs, two facing escarpments of the Wealden anticline, the structure and survival of the plateaux of each are distinct. The palaeo-drainage pattern incised into the South Down is dendritic (Pope et al. 2015), leading back from the scarp, and leaving small, isolated remnants of Clay-with flints and a relatively thin veneer of basal Palaeogene deposits capping only the highest points. In contrast, the North Downs have been eroded in a very different way. Dipping towards the Thames valley, drainage from the scarp has proceeded in a very linear fashion, incising into the Chalk and draining towards the river. The entrenchment of the Thames since MIS 12 has meant that these lines of drainage have themselves become semi-entrenched, cutting the Chalk uplands of the North Downs into linear "slices", resembling a sliced loaf of bread. The preservation of remnant and reworked palaeogene cover (clay-with-flints and, in places, Thanet Sand) is fairly uniform between these "slices", reflecting the fact that the bare bones of the palaeolandscape persist. The Chilterns are in some ways a mixture of both, with river valleys/wind gaps forming deep slices through the Chalk, but also with an extensive dendritic pattern of dry valleys (Catt 2010,94). These regionally variable patterns of erosion and preservation are significant, as they provide different opportunities for release.

A good proxy for the preservation of these palaeolandscapes is provided by the modern distribution of Clay-with-flints in Britain: Clay-with-flints outcrops on the high plateaux and interfluves of the Chalk downs in southern England and north-west France. It formed repeatedly in interglacial periods as a result of the dissolution, decalcification and cryoturbation of Cretaceous and Palaeogene bedrock strata (Catt and Hodgson 1976, 184), and sets hard in dry conditions (Lawrence 2005) protecting the underlying Chalk from erosion (Catt 1986, 157). On the South Downs, the dendritic erosion pattern has largely obliterated the Clay-with-flints (and underlying Chalk), arguably taking any Acheulean archaeology with it, whereas on the North Downs, the "slices" cut through effectively "section" the landscape, providing opportunities for deeply buried Acheulean material (ie. that sealed within dolines) to be released at valley edges.

These differences are writ large when one compares the British and French records. Preservational context varies significantly on both sides of the Channel (depth and distribution of loess cover), but fundamentally, so too does opportunity for release. The loess cover which protects large areas of the North French landscape also prevents deeply buried sites becoming visible (as scarp edge and valley side locations do in southern Britain, through ploughing). Perhaps more importantly, in France, specialist teams of Palaeolithic and Quaternary scientists are more adequately supported to prospect for and excavate this archaeology through INRAP and the CNRS. In comparison with the UK, where archaeological assessment is triggered by proximity to known sites, French rescue archaeology (in Britain, termed "commercial archaeology") often occurs on a landscape scale ahead of infrastructure projects, such as road building and canal constructions which cut across areas of extensive chalkland plateaux. Such projects demonstrate that these areas are actually abundant in artefacts and sites (Locht 2010), even though Palaeolithic archaeology has not previously been recorded within them. As these landscapes are protected from erosion, prior to human release (prospection, excavation and 
development) this material would never have entered the record. Many of these deeply buried sites are exceptionally well-preserved: extensive refitting is possible, allowing fine-grained local chaînes opératoires to be reconstructed, and hearths are, if not common, then at least consistently represented from MIS 8 onwards (Hérrison et al 2013).

There are, therefore, fundamental differences in the way that preservation and release operate across the La Manche chalklands. All of these are explicitly addressed when working from a "site up" perspective (formation processes, geomorphology, capture, history of discovery and collection) but tend to be forgotten when working from site distributions down. It is this tendency to uncritically use patterns drawn from the present known distribution of sites today that we wish to address here. We suggest that it is necessary to understand the taphonomy of whole landscapes (controls on preservation and release), rather than to assume that any artefact, of any date, has an equal chance of entering the record and ending up as a dot on a map.

Working at the scale of the super-region, and the processes that operate across it, we can begin to properly address questions such as the timing of the earliest Acheulean, its apparent efflorescence in MIS11, and subsequent hominin demography both prior to and during the formation of the English Channel itself. In Figure 1 we present a snapshot of the current known distribution of Lower and Middle Palaeolithic sites in the La Manche region. The map as it stands is the product of multiple processes: variation in hominin behaviour, certainly, but also biases in preservation and release. The map widens the scope of enquiry beyond the Acheulean Chalk heartlands, into the western parts of the Channel region with their own distinct record of Palaeolithic archaeology. Thinking of landscape taphonomy on this scale raises some immediate research questions from an UPLA perspective for the entire La Manche region;

1. To what extent is the coastal distribution of sites in the western part of the La Manche region a product of more resistant, persistent coastlines in this area compared to the rapidly eroding Cretaceous and Tertiary coasts of the eastern region?

2. To what extent is the relative absence of sites in the French interior due to hominin preference (i.e. a real absence), or restricted release opportunities in the eastern cretaceous region, coupled with limited research in the western region?

3. To what extent is the relative absence of sites in the western, non-cretaceous region part of the flint effect, with more conservative use of raw materials, localised discard and less prolific handaxe manufacture and discard?

Having outlined the primary differences in release and preservation opportunities across the region, we wish to discuss two specific examples and the effect of these processes upon the Acheulean record. The first example illustrates how the temporal distribution of sites is affected by these factors (the Acheulean record of human demography), whilst the second examines how they impact upon apparent spatial distribution (identifying habitat preference in the Middle Pleistocene). We do not assert that we are unique in stressing that the taphonomy underlying site distribution requires rigorous analysis (see, for example, Ashton et al. 2011 and Davis 2013 for discussions of release opportunities from the fluvial component of the record), but that the record that we are currently working with (especially in Britain) is essentially biased towards the preservation of particular parts of 
the landscape. The following examples illustrate the necessity of addressing both preservation (of the entire landscape) and release opportunities when adopting a "top-down", distribution-led approach.

\section{The Acheulean record of Human Demography: Earliest Appearance.}

In both Britain and northern France, few handaxes predate MIS 15. Ashton et al (2015) summarise the earliest British examples as dating to around 600k BP, whilst Antoine et al (2014) have possible evidence predating 550k BP from the Carpentière quarry in Amiens (Somme). Within this shared cretaceous landscape (Southern Britain / North France) handaxes appear to increase in numbers in MIS 13 and 11, with numbers of handaxes decreasing significantly after this point.

Focusing on the earliest appearance of the Acheulean within the region is important. Historically, the absence of any visible Acheulean signature before the Middle Pleistocene undoubtedly contributed to the development and persistence of a 'Short Chronology' for, firstly Europe as a whole (Roebroeks and Kolfschoten 1994), and latterly for the region (Roebroeks 2001; Roebroeks and Villa 2011; Dennell 2003). The contrasting visibility of core and flake industries as opposed to technologies with handaxes is still a key issue in interpreting the distribution of the record. It is now accepted that hominins with stone tools were present in Europe in excess of one million years ago (de Castro et al 2011) and in Britain/Northern Europe for at least 0.85 million years (Parfitt et al 2010), offering plenty of time and scope for more than one stage of colonisation at the continental scale and multiple, perhaps very sporadic, pulses into northern Europe when climatic conditions allowed. For this crucial period, the record remains sparse: undoubtedly, however, and arguing from a "site up" perspective, people were present across Europe and within its north western limits. However the combination of long scale geomorphological change, the small flake-based nature of the associated lithic industries and perhaps discontinuous regional occupation histories, mean this record is hard to access.

The appearance of Acheulean technologies in Europe leads to a transformation of the available dataset. This is perhaps partly due to how easily identifiable handaxes have historically been when compared to core and flake industries (eg. they are much more likely to be recovered by quarry workers in the course of gravel extraction). Consequently, when one contrasts the European Acheulean record with the record for the earliest sites that precede it, there is a huge asymmetry in the number of known, satisfactorily dated, and adequately investigated early Lower Palaeolithic sites. Comparative artefact visibility aside, one of the key reasons why the "Short Chronology" has unravelled has been the systematic archaeological investigation of deeply buried records revealed only in particular and unusual conditions - sediments which, in the context of the entire landscape, have limited opportunities for release.

The near-sea-level occurrence of artefact bearing deposits from the Early Pleistocene at Happisburgh results from a specific coincidence of tectonic movement and release by rapid sea erosion. In southern Europe, it is notable that both Pirro Nord (Arazello et al 2012) and Atapuerca (Carbonell 1999) occur in karstic capture points within plateau contexts which were artificially released by quarrying and railroad construction. Both sites were well preserved because fluvial drainage patterns had isolated and left intact these landscape blocks through the Pleistocene. Without the impact of specific economic developments, release and discovery would never have occurred.

In the Chalk-rich regions of southern Britain and northern France we concentrate upon here, surviving Early Pleistocene deposits are not to be found in lowland situations, but in plateau contexts, either as 
disturbed fluvial sediments, unhelpful marine deposits (e.g. Nettlebed and Lenham Beds; West 1972), or in poorly understood plateau capture points such as the occurrence of Mammuthus meriodionalis at Dewlish in Dorset (Fisher 1888). The capture point at Westbury Sub-Mendip (Bishop 1974) and the pre-Anglian Acheulean artefacts from Kent's Cavern (Cook and Jacobi 1998), are two examples beyond the Chalk where karstic systems have captured indications of early human occupation which might well relate to occupation above or around the karstic system rather than within it. Making a systematic attempt to investigate beyond the Acheulean event horizon, or to establish more precisely when Acheulean technologies first appeared, requires moving beyond the Middle Pleistocene records of fluvial sedimentary systems and looking for new capture points. We need to ask why there are gaps in site distribution, if we want to extend our knowledge.

\section{Habitat Preference: Working with Asymmetric Records}

A related issue emerges when we consider our current frameworks for understanding preferred habitat preferences. A model for riverine habitat preferences, focused on MIS11, was set out convincingly by Ashton and Lewis (2002), in a nuanced discussion which argued for a lack of association between archaeological material and lacustrine environments, outlined the advantages in terms of resources offered by fluvial valleys, and suggested where plateaux may have played an important role. The latter is of particular interest when considering habitat preference in relation to the UPLA. Ashton and Lewis do not simply provide a polarised model of fluvial systems as preferred niche, but a wholelandscape perspective, working from the sites up, where the river valleys provide advantages at particular times and under particular conditions when compared to other landscape contexts. Conditions during one interglacial may not be the same for others. Indeed, during a single interglacial and habitable phases of the bracketing cold stages, hominin groups may significantly reroute their behaviour and change their landscape preferences. For example, Ashton and Lewis suggest that under cooler, more open conditions, the plateaux may offer more affordances, leading to a less asymmetric record between valley and hill top contexts, with forest cover in interglacials being the most restricting factor in habitation patterns.

A more recent take on the riverine preference model for Middle Pleistocene hominins in Europe has been made by Brown et al. (2013). Here, within a broad 'English Channel' framework, the authors have set out the palaeoecological advantages of hominins establishing niches in the lower reaches of valleys, on the edge of valleys floors, and within valley bottom gravel 'islands'. Whilst aspects of the palaeoecological logic are sensible (valleys are likely to have higher biomass and more diversity of resources), assumed hominin preference for fluvial contexts is based on current distribution maps, aggregating selected parts of both English and French records over a wide variety of time scales and under differing environmental conditions. This is a "top-down", distribution-lead approach which reads current site distribution off with little consideration of how likely evidence of hominin presence in particular parts of the landscape is to be on one hand, preserved, and on the other hand, released.

Critically, the length of time over which particular parts of the landscape accumulated the residues of human activity is not considered. All artefacts are assumed to have entered burial contexts as a result of human presence: however, as many previous workers have pointed out, artefacts actually enter fluvial systems from a wide variety of sources - including reworking from the surrounding landscape. Indeed, Gamble (1996) suggested that this is the strength of these "dredgers" (accumulations of rolled artefacts from river gravels): that they sample behaviour over extended periods of time and 
throughout broad tracts of landscape. Lack of handaxes throughout the generally abraded artefact assemblage from Lower Gravels at Swanscombe has been used to suggest that the Clactonian is a long-lived phenomenon in, at the very least, this part of the Thames Valley during the early Hoxnian (eg. White 2000). Moreover, when likewise using extant distribution maps to investigate demographic patterns, Ashton and Hosfield (2010) and Davies (2013) have demonstrated that numbers of rolled handaxes increase the lower down a given terrace staircase (in this instance, the Solent) is sampled.

Conversely, plateau and interfluve contexts cannot receive artefacts from higher, earlier eroding points in the landscape, relying, therefore, on people to deposit artefacts there. The assemblages recovered from them are sealed by fine-grained sediments (eg. loess), and the human signatures they preserve are frequently fine grained (eg. extensive refitting sequences from Caddington, EtricourtManancourt, Gouzeacourt, Gentelles, to name but a few: Bradley and Sampson 1978, Hérisson and Goval 2013, Tuffreau et al 2008). Thus, they reflect actual human presence at a particular spot, at a particular point in time, not time-averaged human presence throughout an entire river catchment. This, then, is a fundamental asymmetry in the record which a distribution-led analysis can overlook when attempting to analytically segregate the landscape (eg. valley bottom versus interfluve).

Unlike Ashton and Lewis' initial proposal of the habitat preference model, Brown et al (2013) conflate the specifics of time depth and responses to changes through cold-warm stage cycles are thus conflated over several cycles. Considerations of sea-level change at any given point in time are similarly overlooked. More importantly, the nature of the sedimentary system as a whole, and the interplay of behaviour-discard-preservation and release, are not brought together to test the basic distribution maps on which the model is predicated. Put simply, a record within which an entire area of the landscape (plateaux and escarpments) is minimally preserved and even less intensively investigated is used to suggest that this part of the landscape was rarely used. Taking the lesson learnt from the example of the earliest occupation given above, if you are not looking, you will not find it.

While it is highly likely that river valleys were central to early human movement, hunting and foraging activities, this is an assumption which extends back to early accounts of the north European record. If one considers fluvial systems within the context of the north European Chalk regions, there is very little landscape which is not part of active fluvial systems, especially when the now dry periglacial valleys systems are mapped onto them (Figure 2), showing the actual full extent of drainage. Once we eliminate these fluvial systems from our enquiry, and then look at the widely distributed systems of Head deposits, which also contain Acheulean material, we can see that these too map onto the fluvial systems, being part of a single network of valleys which, in the English Channel area, now constitute the sea-flooded headwaters of a single fluvial system. Valley and plateau edges, currently mapped without Head cover, show exposed Cretaceous bedrock which offers no preservational context for Palaeolithic material, whilst the plateau escarpment edges or interfluve contexts have a small but definable record of Palaeolithic occupation.

In order to really bring this mapped distribution pattern into focus, a set of questions needs to be addressed:

1. To what extent is the survival of Pleistocene plateau deposits a consequence of resistance to erosion and, consequently, limited opportunity for release?

2. To what extent are plateau and escarpment edges, important in terms of view and accessibility in the past (eg. see Tuffreau et al. 2008, Hérisson and Locht 2014), under 
represented due to their vulnerability? To what extent are prime locations always on the cutting edge of erosion?

3. To what extent are artefacts, released from plateau and escarpment contexts, transported to fluvial edge contexts for entrainment in fluvial systems? Is there an enrichment over time of fluvial records?

4. How did human behaviour respond to the downward incision of river valleys, creating ever greater asymmetries between the plateau and valley bottom contexts?

The riverine preference hypothesis, while highly likely in its simplest form, is only susceptible to test once these questions, stemming from a more unified landscape perspective sensitive to long term processes, are addressed. One of the authors (LB) is currently testing the distribution of the Acheulean record for the English chalklands, according to the UPLA-derived prediction that preservation and release will explain distribution patterns to a far greater degree than behavioural habitat preference. We feel these questions need to be dealt with before aspects like palaeo-demography and hominin use of landscape in the Middle Pleistocene can be adequately addressed by working from artefact distributions, since the extant record only samples particular parts of the landscape. Again, a useful corrective to assuming that the overall distribution of Acheulean sites (overwhelmingly from fluvial contexts) reflects actual hominin distribution in space is to examine the recent Northern French record, and the ongoing discovery of many extremely rich sites from plateau and escarpment contexts through the adoption of appropriate and large scale prospection techniques (eg. see Locht 2010, Hérisson and Goval 2013).

\section{Applying the UPLA: A case study from the "Acheulean" of the Cretaceous Lower Greensand in Sussex.}

To demonstrate how the approach might be a useful way to think about handaxes distribution data we present a data-led case-study (Pope et al. 2015). In this analysis, we attempted to interpret the apparent high density of handaxes from the Lower Greensand landscape of Sussex (Figure 3). Firstly we established that in terms of artefact density, there was indeed a case to answer and that proportionally more handaxes had been recovered from this geological substrate in the county than any other. Analysis of artefact condition, technology and shape indicated that most could be classified as small cordates and included at least one clear 'Bout Coupe' form. Their condition was either relatively fresh, or differentially patinated. In terms of typology, and read against occurrence of LMP sites within slope deposits at Oldbury (Collins and Collins 1970; Cooke and Jacobi 1998), as well as the discovery of the LMP and early Upper Palaeolithic artefacts preserved in fissures at the site of Beedings (Pope et al 2013), it was considered that most of these handaxe finds could be more easily grouped in with Late Pleistocene, LMP forms than those of the Middle Pleistocene.

If we were to read this record literally we might consider that the Lower Greensand offered some sort of preferred habitat for late Neanderthal groups in the region. But the UPLA forces us to consider process first and in this case, the evidence for the specific mechanism of capture and release associated with the Pleistocene denudation of the Lower Greesand provides another perspective: that the geomorphological history of the Lower Greensand landscapes result from cycles of sediment capture and release, which in turn increased the visibility of artefacts dating to the last cold stage (Devensian). Simply put, older artefacts appeared largely absent from these landscapes (except as part of fluvial sediments), but superficial capture points in hill top and slope 
contexts documented in the landscape as gulls and solution features were providing near-surface preservational environments for the release and recovery of artefacts. This cycle of capture (in the Late Pleistocene) and release (in the Late Glacial/ Holocene) explains the high incidence of handaxes with little in the way of surface patination from these landscapes. The absence of older material from these landscapes can be explained by their release and incorporation into head/fluvial deposits in earlier Glacial-Interglacial cycles.

This interpretative framework, combining landscape distribution, geomorphological process and the results of specific site investigations, suggest that each landscape has its own rhythm of capture and release, controlled by geomorphological processes. For the Lower Greensand the UPLA suggests a sub-100k year cycle after which most artefacts will be incorporated into mobile Head and fluvial systems. Cycles for other geologies now need to established but we might suggest the solution features and Clay-with-flints deposits of the Chalk Downland have 250,000 year cycles, while the deep solution dolines of Limestone plateaux might have cycles in excess of a million years. What the UPLA gives us, when it comes to understanding the distribution of either handaxes or other stone artefacts from the Palaeolithic record, are new scales of analysis, those of variable time depth and process. The plot of handaxe distribution in figure 3 , is not simply one of past human behaviour or recovery, but a differential four-dimensional map of process. This case study suggest that if we are to understand the Acheulean occupation history of Europe (at local, regional or continental scales) a unified approach to differences in landscape development is a necessary adjunct to dots on maps.

\section{Conclusions: Embracing process and testing the record of Acheulean Occupation in Northern Europe.}

The Chalk heartland of northern Europe flanks the hinterlands of the eastern English Channel and French La Manche. It represents a core region for the study of human evolution and offers an unparalleled record of early human landscape use through time. The visibility of the Acheulean record for both regions, compared with the virtual absence of Early Pleistocene core and flake finds as well as the later, more reduced record, for the Middle Palaeolithic, gives the impression of a sudden influx of people between MIS 13 and the end of MIS 11, although the Acheulean has much deeper origins and longer persistence in the region. Being able to disentangle this impression, alongside that of a preference for riverine habitats will take not only new field survey and investigation, but a far more systematic consideration of the datasets we already have.

In this paper we have begun to set out a framework for how we might read the record we have with more discernment, and we have begun to consider the questions necessary to ask. Questions of human behaviour, especially at the site scale, are well within the grasp of modern technological, taphonomic and geoarchaeological analysis. Bigger questions about presence, absence, preference and movement within the landscape, their change through deep time and in response to climatic and environmental change over shorter timescales are more difficult to answer. The Chalk landscapes of north Europe are soft and fragile, and, during the timescales with which we are concerned, have experienced geomorphological change due to multiple agents. The extent of landscape change within the Early and Middle Pleistocene is only broadly appreciable, and key questions regarding issues such as scarp recession and rate of removal of Tertiary cover lie beyond our current knowledge.

Until key geomorphological questions such as these are addressed, it is impossible to calibrate our record for the appearance and proliferation of the Acheulean in any meaningful way. Some of these 
questions may have been raised before but we suggest, from the first stages of project design they should be openly and directly addressed.

Ultimately, and alongside changes in research methodology, we need to use our imaginations in new thought-experiments of landscape change, as vivid as those we develop for past human behaviour. This should always be our first step, only later using them to isolate the variables we can test though new field and archive analysis. The greatest challenge is to develop fieldwork approaches which do not atomise the record into plateau, raised beach or river terrace contexts, nor address single time periods, but which instead cut across the spatial and temporal boundaries to develop models of landscape change which embrace process. The process-led Unified Palaeolithic Landscape Approach, with its stepwise emphasis on release, preservation, discard and behaviour offers a framework through which to embrace this complexity and develop a new perspective on the Lower Palaeolithic record of the north European Acheulean.

\section{Acknowledgements}

The authors would like to thank the following for inspiring discussions, and helpful advice in preparing this manuscript: John Catt, Martin Bates, David Bridgland, Peter Allen, Clive Gamble, Andy Shaw, Andrew Garrard, Geoff Halliwell, Ed Blinkhorn, Dave Bone and Julian Murton. Dr Scott's contribution to this paper forms part of the Pathways to Ancient Britain (PAB) project, supported by the Calleva Foundation

\section{References}

Arzarello, M., Pavia, G., Peretto, C., Petronio, C., and Sardella, R. 2012. Evidence of an early Pleistocene hominin presence at Pirro Nord (Apricena, Foggia, southern Italy): P13 site. Quaternary International, 267, 56-61.

Antoine, P., Lozouet, N. L., Chaussé, C., Lautridou, J. P., Pastre, J. F., Auguste, P. and Galehb, B. 2007. Pleistocene fluvial terraces from northern France (Seine, Yonne, Somme): synthesis, and new results from interglacial deposits. Quaternary Science Reviews, 26 (22), 2701-2723.

Antoine, P., Moncel, M. H., Locht, J. L., Limondin-Lozouet, N., Auguste, P., Stoetzel, E. and Falgueres, C. 2015. Dating the earliest human occupation of Western Europe: New evidence from the fluvial terrace system of the Somme basin (Northern France). Quaternary International, 370, 77-99 .

Ashton, N, Lewis, S.G. and Harris, C.R.E., 2015. The distribution of early Palaeolithic sites in Britain. In: Ashton, N. and Harris, C. (eds.). No Stone Unturned. Papers in Honour of Roger Jacobi. London: Lithic Studies Society, 19-30.

Ashton, N., and Lewis, S. 2002. Deserted Britain: declining populations in the British late Middle Pleistocene. Antiquity, (292), 388-396.

Ashton, N., and Hosfield, R. 2010. Mapping the human record in the British early Palaeolithic: evidence from the Solent River system. Journal of Quaternary Science, (5), 737-753 
Ashton, N.M., Lewis, S.G. and Hosfield, R. 2011. Mapping the human record: Population change in Britain during the later Middle Pleistocene. In: Ashton, N.M., Lewis, S.G. and Stringer, C.B. (eds.). The Ancient Human Occupation of Britain. Amsterdam: Elsevier, 39-51.

Bishop, M. J. 1974. A preliminary report on the Middle Pleistocene mammal bearing deposits of Westbury-Sub-Mendip, Somerset. Proc. Univ. Bristol Spelaeol. Soc, 13(3), 301-18.

Bradley, B. and Sampson, C.G., 1978. Artifacts from the Cottages site. In: Sampson, C.G. (ed). Palaeoecology and Archaeology of an Acheulean Site at Caddington, England. Dallas: Southern Methodist University, 83-137.

Bridgland, D. R. 1994. Quaternary of the Thames (Geological Conservation Review Series Vol. 7). London: New York: Chapman Hall.

Bridgland, D. R. 2006. The Middle and Upper Pleistocene sequence in the Lower Thames: a record of Milankovitch climatic fluctuation and early human occupation of southern Britain: Henry Stopes Memorial Lecture 2004. Proceedings of the Geologists' Association, 117 (3), 281-305.

Brown, A. G., Basell, L. S., Robinson, S., and Burge, G. C. 2013. Site distribution at the edge of the Palaeolithic world: a nutritional niche approach. PLOSONE

8(12):e81476.doi:10.1371/journal.pone.0081476

Carbonell, E., Garcí, M., Mallol, C., Mosquera, M., Ollé, A., Sahnouni, M. and Vergès, J. M. 1999. The TD6 level lithic industry from Gran Dolina, Atapuerca (Burgos, Spain): production and use. Journal of Human Evolution, 37(3), 653-693.

Catt, J.A. 1986. The nature, origin and geomorphological significance of clay-with-flints. In: Sieveking, G. de G. and Hart, M.B. (eds). The Scientific Study of Flint and Chert: Proceedings of the Fourth International Flint Symposium held at Brighton Polytechnic 10-15 April 1983. Cambridge: Cambridge University Press, 151 -159.

Catt, J. 2010. Neogene deposits and early landscape development. In: Catt, J. (ed.) Hertfordshire Geology and Landscape. Welwyn Garden City: Hertfordshire Natural History Society, 79-117.

Catt, J.A. and Hodgson, J.M. 1976. Soils and geomorphology of the Chalk in south-east England. Earth Surface Processes, 1, 181-193.

Collins, D., and Collins, A. 1970. Excavations at Oldbury in Kent: cultural evidence for Last Glacial occupation in Britain. Bulletin of the Institute of Archaeology, 8, 151-176.

Conneller, C. 2011. An archaeology of materials: substantial transformations in early prehistoric Europe. Routledge.

Cook, J., and Jacobi, R. 1998. Discoidal core technology in the Palaeolithic at Oldbury, Kent. In: Ashton, N., Healy, F. and Pettit, P. (eds). Stone Age Archaeology: Essays in Honour of John Wymer. Oxford: Oxbow Books, 124-136.

Cook, J., and Jacobi, R. 1998. Observations on the artefacts from the Breccia at Kent's Cavern. In: Ashton, N., Healy, F. and Pettit, P. (eds.). Stone Age Archaeology: Essays in Honour of John Wymer. Oxford: Oxbow Books, 77-89. 
Davis, R.J. 2013. Palaeolithic Archaeology of the Solent River: Human Settlement History and Technology. Unpublished PhD thesis, University of Reading.

de Castro, J.M.B., Martinón-Torres, M., Gómez-Robles, A., Prado-Simón, L., Martín-Francés, L., Lapresa, M., Olejniczak, A. and Carbonell, E. 2011. Early Pleistocene human mandible from Sima del Elefante (TE) cave site in Sierra de Atapuerca (Spain): a comparative morphological study. Journal of Human Evolution, 61(1), pp.12-25.

Dennell, R. 2003. Dispersal and colonisation, long and short chronologies: how continuous is the Early Pleistocene record for hominids outside East Africa? Journal of Human Evolution, 45(6), 421440.

Fisher, O. 1888. On the Occurrence of Elephas meridionalis at Dewlish, Dorset. Quarterly Journal of the Geological Society, 44(1-4), 818-824.

Gamble, C. S. 1996. Hominid behaviour in the Middle Pleistocene: an English perspective. In: Gamble, C. and Lawson, A.J. (eds). The English Palaeolithic Reviewed. Papers from a Day Conference Held at the Society of Antiquaries of London, 28 October 1994. Trust for Wessex Archaeology, 63-71.

Gamble, C., and Kruszynski, R. 2009. John Evans, Joseph Prestwich and the stone that shattered the time barrier. Antiquity, 83(320), 461-475.

Haase, D., Fink, J., Haase, G., Ruske, R., Pesci, M., Richter, H., Altermann, M. and Jager, K.-D. 2007. Loess in Europe - its spatial distribution based on a European loess map, scale 1:2,500,000. Quaternary Science Reviews 26, 1301-1312. doi:10.1016/j.quascirev.2007.02.003.

Hallos, J. 2005. "15 Minutes of Fame": Exploring the temporal dimension of Middle Pleistocene lithic technology. Journal of Human Evolution 49, 155-179.

Hérisson, D. and Goval, E. 2013. Du Paléolithique inférieur au debut du Paléolithique supérieur dans le Nord de la France: lumière sur les premieres découvertes du Canal Seine-Nord Europe. Notae Praehistoricae 33, 91-104.

Hérisson, D. and Locht, J-L. 2014. Le niveau N3 de Therdonne : reflet de la diversité des technocomplexes du Paléolithique moyen ancien du Nord de la France ? In : Jaubert, J., Fourment, N. and Depaepe, P. (eds.)Transitions, ruptures et continuité en Préhistoire: XXVIle Congrès Préhistorique Bordeaux de France 2010. Paris : Société Préhistorique Française, 43-58.

Hérisson, D., Locht, J-L., Auguste, P. and Tuffreau, A. 2013. Néandertal et le feu au Paléolithique moyen ancien. Tour d'horizon des traces de son utilisation dans le Nord de la France.

L'Anthropologie 117, 541-578

Hosfield, R. (1999). The Palaeolithic of the Hampshire Basin: A regional model of hominid behaviour during the Middle Pleistocene. Oxford: Archaeopress.

Kolen, J., De Loecker, D., Groenendijk, A. J. and De Warrimont, J. P. 1999. Middle Palaeolithic surface scatters: how informative? A case study from southern Limburg (the Netherlands). In: Roebroeks, W. and Gamble, C. (eds). The Middle Palaeolithic Occupation of Europe. Leiden: Leiden University Press, 172-192. 
Lawrence, U. 2005. The Engineering Geology of the Clay-with-flints (As shown on the British Geological Survey 1:50,000 New Series Geological Sheets). University of Surrey School of Engineering. Unpublished PhD thesis.

Locht, J. L. 2010. La détection des sites du Paléolithique ancien et moyen dans le nord de la France : une approche particulière. In : Depaepe P., and Séara, F. (Eds.) Le diagnostic des sites paléolithiques et mésolithiques. Cahiers de I'INRAP 3, 49-57.

Locht, J-L., Goval, E., Antoine, P., Coutard, S., Auguste, P., Paris, C., and Hérisson, D. 2014. Palaeoenvironments and prehistoric Interactions in Northern France from the Eemian interglacial to the end of the Weichselian Middle Pleniglacial. In: Foulds, F.W.F., Drinkall, H.C., Perri, A.R., Clinnick, D.T.G. and Walker, J.W.P. (eds). Wild Things: Recent Advances in Palaeolithic and Mesolithic Research, 70-78.

McNabb, J. 2011. The British Lower Palaeolithic: Stones in Contention. Abingdon: Routledge.

Murton, J.B., Baker, C., Bateman, M.D. and Whiteman, C.A., 1998. Pegwell Bay, Cliffsend (TR354644362642). In: Murton, J.B., Whiteman, C.A., Bates, M.R., Bridgland D.R., Long, A.J., Roberts, M.B. and Waller, M.P.L. (eds). The Quaternary of Kent and Sussex Field Guide. London: Quaternary Research Association, 35-38.

Murton, J.B. and Latridou, J-P. 2003. Recent advances in the understanding of Quaternary periglacial features of the English Channel coastlands. J. Quaternary Sci. 18:301-307. doi:10.1002/jqs.748

Parfitt, S. A., Barendregt, R. W., Breda, M., Candy, I., Collins, M. J., Coope, G. R. and Stuart, A. J. 2005. The earliest record of human activity in northern Europe. Nature, 438(7070), 1008-1012.

Parfitt, S. A., Ashton, N. M., Lewis, S. G., Abel, R. L., Coope, G. R., Field, M. H. and Stringer, C. B. 2010. Early Pleistocene human occupation at the edge of the boreal zone in northwest Europe. Nature, 466(7303), 229-233.

Pope, M., Blundell, L., Cutler, H. and Scott, B. 2015. At the headwaters of the English Channel River: considering Late Neanderthal archaeology in the Sussex Weald. In: Ashton, N. and Harris, C. No Stone Unturned: Papers in Honour of Roger Jacobi. Lithic Studies Society Occasional Paper 9. London: Lithic Studies Society, 31-42.

Prestwich, J., 1859. On the Occurrence of Flint-Implements, Associated with the Remains of Extinct Mammalia, in Undisturbed Beds of a Late Geological Period. Proceedings of the Royal Society of London, 10, pp.50-59.

Roberts, M.B. and Parfitt, S.A., 1999. Boxgrove. A Middle Pleistocene Hominid Site at Eartham Quarry. Boxgrove, West Sussex. London: English Heritage.

Roe, D. A. 1964. The British Lower and Middle Palaeolithic: some problems, methods of study and preliminary results. Proceedings of the Prehistoric Society (New Series), 30, 245-267.

Roe, D. 1968. A Gazetteer of British Lower and Middle Palaeolithic sites. York: Council for British Archaeology, 355. 
Roe, D. A. 1981a. Amateurs and archaeologists: some early contributions to British Palaeolithic studies. In: Evans, J.D., Cunliffe, B. and Renfrew, C. (eds). Antiquity and Man: Essays in Honour of Glyn Daniel, London: Thames and Hudson, 214-220.

Roe, D. A. 1981b. The Lower and Middle Palaeolithic Periods in Britain. London: Routledge.

Roebroeks, W., and Kolfschoten, T. V. 1994. The earliest occupation of Europe: a short chronology. Antiquity, 68 (260), 489-503.

Roebroeks, W. 2001. Hominid behaviour and the earliest occupation of Europe: an exploration. Journal of Human Evolution, 41(5), 437-461.

Roebroeks, W. and Villa, P. 2011. On the earliest evidence for habitual use of fire in Europe. Proceedings of the National Academy of Sciences, 108(13), 5209-5214.

Roebroeks, W., Conard, N. J., Van Kolfschoten, T., Dennell, R. W., Dunnell, R. C., Gamble, C. and Wymer, J. J. 1992. Dense forests, cold steppes, and the palaeolithic settlement of northern europe [and comments and replies]. Current Anthropology 33 (5), 551-586.

Schlanger, S. H. 1992. Recognizing persistent places in Anasazi settlement systems. In: Rossignal, J and Wandsnider, L. (eds.). Space, Time, and Archaeological Landscapes. The Society for American Archaeology Meeting 1988, Phoenix Arizona. New York: London: Plenum Press, 91-112.

Scott, R. 2011. Becoming Neanderthals: The Earlier British Middle Palaeolithic. Oxbow Books.

Scott, B., and Ashton, N. 2011. The Early Middle Palaeolithic: The European Context. In: Ashton, N., Lewis, S.G. and Stringer, C. (eds). The Ancient Human Occupation of Britain. Developments in Quaternary Science 14, Elsevier: Amsterdam, 91-112.

Shackleton, N. J. and Opdyke, N. D. 1973. Oxygen isotope and palaeomagnetic stratigraphy of Equatorial Pacific core V28-238: oxygen isotope temperatures and ice volumes on a $10^{5}$ year and $10^{6}$ year scale. Quaternary Research, 3(1), 39-55.

Tuffreau,A., Lamotte, A., and Goval, E. 2008. Les industries acheuléennes de la France septentrionale. L'Anthropologie 112, 104-139

Tuffreau, A., Lamotte, A. and Marcy, J.-L., 1997. Land-use and site function in Acheulean complexes of the Somme Valley. World Archaeology 29, 225-241.

Wessex Archaeology, 1993. The Southern Rivers Palaeolithic Project Report No. 2; Region 4 (South of the Thames) and Region 1 (South West England). Salisbury: Trust for Wessex Archaeology.

West, R. G. 1972. Relative land-sea-level changes in southeastern England during the Pleistocene. Philosophical Transactions of the Royal Society of London. Series A, Mathematical and Physical Sciences 272(1221), 87-98.

White, M.J. 2000. The Clactonian question: on the interpretation of Core-and-Flake assemblages in the British Lower Palaeolithic. Journal of World Prehistory 14, 1-63 
White, M. J., and Schreve, D. C. 2000. Island Britain-peninsula Britain: palaeogeography, colonisation, and the Lower Palaeolithic settlement of the British Isles. In: Proceedings of the Prehistoric Society 66, 1-28.

Williams, R.B.G., 1965. Permafrost in England during the Last Glacial Period. Nature 205, 1304-5.

Wymer, J. 1968. Lower Palaeolithic Archaeology in Britain as Represented by the Thames Valley. London: John Baker.

Wymer, J. 1985. The Palaeolithic sites of East Anglia. Norwich: Geo Books.

Wymer, J., 1999 The Lower Palaeolithic Occupation of Britain. Salisbury: Trust for Wessex Archaeology.

\section{Figure List and Captions}

Figure 1: Mapped distribution of Lower and Middle Palaeolithic find spots in the La Manche region.

Figure 2: Head and fluvial sediments forming a single, evolving sedimentary system related to the dissection of Cretaceous geologies. An example from the South Downs around Brighton and Hove (Drawing by Justin Russell)

Figure 3: The occurrence of handaxes, thought to be of Late Middle Palaeolithic derivation, and their association with Cretaceous Lower Greensand geology. (From Pope et al. 2015). 